\title{
Some remarks on the semantics of ir ('go') + Infinitive in European Portuguese
}

\section{Luís Filipe Cunha}

Centro de Linguística da Universidade do Porto / Faculdade de Letras da Universidade do Porto

Via Panorâmica, S/N, 4150-564, Porto, Portugal

luisfilipeleitecunha@gmail.com

Thispaperisfundedby Fundação para a Ciência e a Tecnologia, QREN - POPH - Tipologia 4.1. - formação

\section{ABSTRACT} avançada, comparticipado pelo Fundo Social Europeu e pelo MEC

This paper deals with the semantics of the European Portuguese structure ir ('go') + Infinitive, in particular when it occurs with the PretéritoPerfeito (a terminative past tense) and the Presente do Indicativo (Simple Present). We will argue for the hypothesis that, indeed, in this language there are two different semantic configurations behind the ir ('go') + Infinitive sequence. In fact, we will begin describing a first reading in which ir ('go') seems to retain most of its basic lexical properties, imposing strong restrictions to the situations that can combine with it, concerning particularly their aspectual profile and the presence or absence of the agentive feature; then, we will explore a second interpretation in which ir ('go') behaves like a pure temporal operator of futurity, exhibiting the characteristics of a semi-auxiliary and imposing no relevant constraints to the eventualities that co-occur in the whole structure.

\section{Indexing Terms/KeyWords:}

Semantics; ir ('go') + Infinitive; Tense; Aspect; Portugueselanguage.

\section{Academic Discipline andSub-Disciplines}

Linguistics, Semantics

\section{Council for Innovative Research}

Peer Review Research Publishing System

Journal: Journal of Advances in Linguistics

Vol.5 No 3

editor@cirjal.com

www.cirjal.com, 


\section{INTRODUCTION}

It has been widely observed by several linguists that, in European (and Brazilian) Portuguese, the use of the verb ir ('go') + the simple form of the Infinitive constitutes one of the most frequent and productive constructions to express temporal posteriority (see, among many others, Oliveira, 1986; Peres, 1993; Oliveira \& Lopes, 1995; Silva, 1997). However, as we will argue in this paper, the combination of ir ('go') with the infinitive poses intriguing questions that should be carefully nalysed. In fact, although irco-occurs with the simple infinitive forms in all possible Portuguese tenses, there are some important combinatorial restrictions and semantic differences that call for an explanation.

As an example of the above-mentioned discrepancies, take the sentences in (1) and (2): whereas ir ('go') + Infinitive with the Presente do Indicativo (a simple present tense) freely combines with stative predications (cf. (1)), the same linguistic structure occurring with the PretéritoPerfeito (a terminative past tense)systematically rules out the presence of states as its complement (cf. (2)).

(1) O João vai ser médico.

«theJoãoir-3.sg.Pres to-be doctor ${ }^{1}$

«João will be a doctor.»

(2) * O João foi ser médico.

«The Joãoir-3.sg.PPerf to-be doctor»

Taking as a departure point differences in linguistic behaviour like the ones presented in (1) and (2), I will develop the hypothesis that, in Portuguese, ir('go') + Infinitive takes part in more than one singlelinguistic configuration, i.e., that there is enough linguistic evidence to argue in favour of the existence of two distinct constructions involving ir('go') + Infinitive.

Thus, it will be important to discuss the following relevant problems: (i) How can we characterise and describe the combinatorial restrictions exhibited by ir ('go') + Infinitive? (ii) What linguistic factors must be taken into account in order to license each reading? (iii) What is the role played by the verb ir ('go') in these constructions?

In order to illustrate the need for the postulation of the two above-mentioned structures involving ir ('go') + Infinitive, I will mainly take into account its behaviour with the Pretérito Perfeito (PPerf) and the Presente (Pres), leaving aside other Portuguese tenses like the Imperfeito (the imperfective past), since they raise additional problems and interpretations that can't be fully addressed in this text.

The paper is organised as follows: In section 2, I will present the ir ('go') + Infinitive construction with the PPerf tense, demonstrating that it is associated with a number of strong combinatorial constraints that can only be accounted for if we take the verb ir ('go') as a "full" lexical item. In section 3, I will explore the ir ('go) + Infinitive construction with the Present tense and recognise the emergence of two different readings: a quantificational one in which the verb ir ('go') presents similar restrictions it did with the PPerf and a temporal one in which it is grammaticalised as part of a future tense structure. Section 4 briefly discusses the performance of ir + Infinitive with other Portuguese tense forms and, finally, section 5 summarises and concludes our findings.

\section{IR ('GO') + INFINITIVEWITHTHEPRETÉRITO PERFEITO (PPERF)}

The combination of ir ('go') + Infinitive with the PPerf tense is perfectly possible and acceptable in EP, as the following sentences, taken from our corpus, ${ }^{2}$ demonstrate.

(3) Sampaio foi mostrar as marchas das regiões. (par=ext18240-pol-96a-1)

«Sampaioir-3.sg.PPerf to-show the marches of-the regions»

"Sampaio went (there) to show the marches of the regions."

(4) O Público foi assistir aos ensaios. (par=ext347503-soc-97a-4)

«The Públicoir-3.sg.PPerf to-attend at-the rehearsals»

«The Público went to attend the rehearsals.»

In spite of its relatively high frequency in EP, the ir('go') + Infinitive construction with PPerf is constrained by some important restrictions, particularly concerning the aspectual properties of the situation that occurs in the Infinitive form. Consider the following examples:

\footnotetext{
${ }^{1}$ In the examples presented in this paper, I will use the following notation and abbreviations attached to the verbs: 1 : first person; 3: third person; sg: singular; pl: plural; Pres: Present; Imp: Imperfect; PPerf: PretéritoPerfeito(terminative past tense); Fut.Subj: Future of the Subjunctive; MQPerf-Comp: Mais-que-PerffeitoComposto (pluperfect); PPerf-Comp: PretéritoPerfeitoComposto (compound past tense).

${ }^{2}$ In the course of this paper, I will seldom use examples taken from a corpus containing texts from a Portuguese newspaper, the Cetempúblicocorpus, available at www.linguateca.pt, in order to validate some of my observations with "real" produced sentences.
} 
(5) O Luís foi comprar um chocolate.

«The Luísir-3.sg.PPerf to-buy a chocolate»

«Luís went (there) to buy a chocolate.»

(6) A Maria foi telefonar à irmã.

«The Maria ir-3.sg.PPerf to-phone at-the sister»

«Maria went (there) to call her sister.»

(7) * O Luís foi gostar de linguística.

«The Luísir-3.sg.PPerf to-like of linguistics»

«Luís went (there) to like linguistics.»

(8) * A Maria foi estar em casa.

«The Maria ir-3.sg.PPerf to-be in house»

«Maria went (there) to be at home.»

It is important, thus, to find out what linguistic factors are relevant in the licensing of these sentences in order to capture the contrasts just presented. In the next paragraphs, I will explore some hypotheses so that we can get an adequate description of the pattern of occurrences associated with ir ('go') + Infinitive in the context of the PPerf tense.

\section{A. The stative/non stative hypothesis}

In a first approach to the contrasts under analysis, we could suppose that the constraints associated to the occurrence of ir ('go') + Infinitive in the PPerf depend on the aspectual class of the predication in the Infinitive form. In fact, only eventive situations seem to occur unproblematically in such contexts (cf. (9)-(12)), contrary to stative ones, which, normally, cause semantic anomaly in similar circumstances (cf. (13)-(15)). ${ }^{3}$

(9) O João foi correr com os amigos. (process)

«The Joãoir-3.sg.PPerf to-run with the friends»

«João went (there) to run with his friends.»

(10) O Zé foi montar a tenda. (culminatedprocess)

«The Zéir-3.sg.PPerf to-assemble the tent»

«Zé went (there) to assemble his tent.»

(11) A Teresa foi abrir a porta. (culmination)

«The Teresa ir-3.sg.PPerf to-open the door»

«Teresa went (there) to open the door.»

(12) O Cristiano Ronaldo foi chutar a bola. (point)

«The Cristiano Ronaldo ir-3.sg.PPerf to-kick the ball»

«Cristiano Ronaldo went (there) to kick the ball.»

(13) * A Maria foi ter olhos azuis. (non-phase individual-level state)

«The Maria ir-3.sg.PPerf to-have eyes blue»

«Maria went (there) to have blue eyes.»

(14) * O Miguel foi ser prestável com os colegas. (phaseindividual-levelstate)

«The Miguel ir-3.sg.PPerf to-be helpful with the colleagues»

«Miguel went (there) to be helpful to his colleagues.»

(15) * O Pedro foi estar doente. (stage-levelstate)

«The Pedro ir-3.sg.PPerf to-be sick»

«Pedro went (there) to be sick.»

\footnotetext{
${ }^{3}$ In this paper, I follow the classification of Moens (1987) for events. Concerning statives, I take the classification presented in Cunha 2004; 2007; 2013.
} 
Though, at first sight, it seems rather appealing, this hypothesis faces a number of serious problems that render it inappropriate to describe the data under discussion.

Firstly, it is not difficult to find examples in which events cannot combine with ir ('go') + Infinitive in the PPerf, as the following sentences illustrate:

(16) * Foichover. (process)

«Ir-3.sg.PPerf to-rain»

«lt went to rain.»

(17) * O fogo foi queimar a mata. (culminatedprocess)

«The fire ir-3.sg.PPerf to-burn the forest»

«The fire went (there) to burn the forest.»

(18) * O João foi partir o braço. (culmination)

«The Joãoir-3.sg.PPerf to-break the arm»

«João went (there) to break his arm.»

On the other hand, it is possible to discover, though in very restricted and special contexts, some perfectly grammatical stative predications combined with ir ('go') + Infinitive in the PPerf, as shown in (19):

(19) Muitos habitantes das cidades deixaram a Bósnia e foram viver para a Escandinávia, Estados Unidos, Canadá e Austrália. (par=ext5180-nd-96b-1)

«Many inhabitants of-the cities leave-3.pl.PPerf the Bonsia and ir-3.pl.PPerf to-live to the Scandinavia, United States, Canada and Australia»

«Many city dwellers left Bosnia and went to live in Scandinavia, the United States, Canada and Australia.»

Finally, it is important to point out that there are some eventualities that exhibit variation regarding their acceptability under the construction ir ('go') + Infinitive in the PPerfdependinguniquely on the selection of their external argument, as demonstrated by the pair of sentences in (21) and (22). In fact, these predications share the same aspectual class and even the same verb and internal argument in their structure, the only changing element being the argument in the subject position of the sentence. We can, therefore, conclude that, in a way or another, the status of the subjectmust be related to the differences that are observed in these examples.

(20) O João foi podar as árvores.

«The Joãoir-3.sg.PPerf to-prune the trees»

«João went (there) to prune the trees»

$(21)^{*}$ A tesoura foi podar as árvores.

«The scissors ir-3.sg.PPerf to-prune the trees»

«The scissors went (there) to prune the trees.»

Taking into account that (i) there are some events that are completely incompatible with ir ('go') + Infinitive in the PPerf; (ii) there are some states that, in appropriate conditions, can combine with that structure and (iii) the external argument of some verbs seems to play an important role in the licensing of eventualities in the referred context, we must conclude that the aspectual hypothesis based uniquely on the stative/non stative contrast must be discarded and an alternative explanation must instead be pursued.

\section{B. The agentive/non agentive hypothesis}

Taking into account the set of examples just presented and, in particular, contrasts such as the one illustrated in (20)-(21), it would be reasonable to suggest the hypothesis that only agentive predications could occur with ir ('go') + Infinitive in the PPerf, being non-agentive situations ruled out in thesame context. The following pairs of sentences seem to confirm such analysis. 
(22) O Joãofoitrabalhar.

«The Joãoir-3.sg.PPerf to-work»

«João went (there) to work.»

(23) * O motor do meu carro foi trabalhar.

«The engine of-the my car ir-3.sg.PPerf to-work»

«My car's engine went (there) to work.»

(24) $O$ exército foi destruir a cidade.

«The army ir-3.sg.PPerf to-destroy the city»

«The army went (there) to destroy the city.»

(25) * A tempestade foi destruir a cidade.

«The storm ir-3.sg.PPerf to-destroy the city»

«The storm went (there) to destroy the city.»

Although it solves some of the problems left unresolved by the aspectual solution, this analysis, however, is not entirelysuitable. In particular, it turns out to be problematic when we consider the existence of agentive states.

Indeed, in the literature about aspect, the agentive behaviour of some stative predications was unequivocally identified and fully described (see, among others, Dowty, 1979; Cunha, 2007). As a simple example, consider the Portuguese predication "O Miguel sergeneroso" («Miguel be generous»): as the following patternof occurrences confirms, this kind of stative is plainlywell-suited with all tests traditionally invoked to recognise the presence of an agentive situation. In particular, it co-occurs with imperatives (cf. (26)), it is compatible with agentive adverbials such as voluntariamente («voluntarily») or deliberadamente («deliberately») (cf. (27)) and it freely combines with agentive verbs like forçar («to force») and persuadir («to convince») (cf. (28)):

(26) Miguel, sêgeneroso!

«Miguel, ser-2.sg.Imper generous»

«Miguel, begenerous!»

(27) O Miguel foi generoso voluntariamente.

«The Miguel ser-3.sg.PPerf generous voluntarily»

«Miguel was voluntarily generous.»

(28) A mãe obrigou o Miguel a ser generoso.

«The mother forçar-3.sg.PPerf the Miguel to to-be generous»

«His mother forced Miguel to be generous.»

An obvious consequence of the hypothesis developed so far would be the unproblematic compatibility of these agentive states with the construction ir ('go') + Infinitive in the PPerf. Nonetheless, this prediction is not born out, as the following examples illustrate:

(29) * O Miguel foi ser generoso.

«The Miguel ir-3.sg.PPerf to-be generous»

«Miguel went (there) to be generous.»

(30) * O Jorge foi estar quieto.

«The Jorge ir-3.sg.PPerf to-be quiet»

«Jorge went (there) to be quiet»

Though the statives in (29) and (30) are clearly agentive, they produce semantic anomaly in the context of ir('go') + Infinitive in the PPerf, contrary to our expectations.

The observation that the vast majority of agentive states leads to semantic anomaly in the context of the construction ir ('go') + Infinitive in the PPerf, as illustrated above, strongly suggests that the view according to which agentivity would be 
the main factor involved in the selection of predications by this structure does not satisfactorily describe all the linguistic data under discussion and, therefore, the problems we have just exposed claim for a more detailed explanation.

\section{The lexical hypothesis}

A third hypothesis to explain the constraints associated to the ir ('go') + Infinitive in the PPerf construction would be to consider that, in this structure, the verb ir ('go') maintains a significant number of its basic lexical properties. In other words, both the verb ir ('go') in the PPerf tense and the infinitive predication with which it combines contribute lexically for the whole reading of the sentence.

In order to validate this proposal, it is important to provide linguistic evidence that supports our claim. Let us, thus, briefly discuss some of the most prominent properties of the verb ir ('go') taken as a pure lexical item and relate them with the restrictions we have been dealing with. ${ }^{4}$

In its basic lexical function, ir ('go') typically describes a "trajectory" or a "path". As a consequence, it is involved in dynamic predications, i.e., events that are constituted by divisible successive subphases (cf. Dowty, 1979; Binnick, 1991).

Dynamicity would, then, be responsible for the fact that ir ('go') normally produces semantic anomaly when it is combined with stative predicates, as we observed in examples like (7)-(8) or (29)-(30), since, as part of their definition, states are characterised by the feature [-dynamic].

Another relevant property that is used to characterise the verb ir ('go') in its pure lexical use is agentivity, or, perhaps more accurately, its tendency to combine with an animate external argument. In fact, the predications involving this verb typically require a controller subject, as the following contrasting sentences demonstrate: ${ }^{5}$

(31) Os rapazes foram à praia.

«The boysir-3.pl.PPerf to-the beach»

«The boys went to the beach.»

(32) * As pedras foram à praia.

«The stones ir-3.pl.PPerf to-the beach»

«The stones went to the beach.»

(33) O Filipe foi para a escola.

«The Filipe ir-3.sg.PPerf to the school»

«Filipe went to school.»

(34) * A mochila foi para a escola.

«The backpack ir-3.sg.PPerf to the school»

«The backpack went to school.»

So, if ir('go') in the ir('go') + Infinitive withPPerf construction behaves just like the full lexical verb illustrated above, it will have agentivity(or animacity) as one of its characterising properties (but, since it is also a dynamic verb, not all agentive propositions will be compatible with it: in particular, agentive states will produce semantic anomaly).

In sum, if we assume that it is the verb ir ('go') taken as a full lexical item that is involved in the construction we are dealing with in this section, we will find a good explanation for the data under analysis. On the one hand, since ir ('go') ordinarily

\footnotetext{
${ }^{4}$ For a detailed discussion about some semantic properties of the verb ir ('go'), taken as a pure lexical item, in Brazilian Portuguese, see Oliveira (2010).

${ }^{5}$ It is important to stress that ir («go'), taken as a pure lexical item, can only be partially considered an agentive verb. In fact, though it is normally not compatible with non-agentive external arguments, as illustrated in (32) and (34), ir ('go'), in its lexical use, can, nevertheless, combine with this kind of subjects in appropriate contexts, as (i) and (ii) demonstrate:
}

\section{A nave Apollo 11 foi à Lua em 1969.}

«The spacecraft Apollo 11 ir-3.sg.PPerf to-the moon in 1969»

«The Apollo 11 spacecraft went to the moon in 1969.»

(ii)

As malas foram para o porão do navio.

«The bags ir-3.pl.PPerf to the hold of-the ship»

«The bags went to the ship's hold.»

Given that the leading object of analysis of this paper is the construction ir ('go') + Infinitive and not the full lexical verbir ('go') followed by a PP, I will leave for another opportunity the study of the conditions under which it can be compatible with non-agentive/non-animate external arguments. 
requires a controller subject, it will be preferentially compatible with agentive eventualities, ruling out non-agentive ones, as observed in examples (16)-(18), (21), (23) and (25). Moreover, since this verb occurs inthe context of dynamic situations, statives(independently of their agentivity) are typically incompatible with sentences containing it (cf. (7)-(8), (29)-(30)). ${ }^{6}$

Another piece of evidence we can invoke in favour of this analysis has to do with the argumental properties of the verb: taken as a full lexical item, ir('go') normally selects an argument with the semantic role of Goal, which is typically performed by a Prepositional Phrase headed by a ('to') or bypara ('to'), as shown in the following examples:

(35) O João foi ao cinema.

«The Joãoir-3.sg.PPerf to-the cinema»

«João went to the cinema.»

(36) Os gnus foram para o Quénia.

«The gnusir-3.pl.PPerf to the Kenya»

«The gnus moved to Kenya.»

Whenever ir ('go') in the PPerf occurs with Infinitive forms, it is always possible (though not mandatory) to introduce a PP displaying similarproperties, as exemplified by the following sentences.

(37) A Cristina foi almoçar à Foz.

«The Cristina ir-3.sg.PPerf to-have-lunch to-the Foz»

«Cristina went to Foz to havelunch.»

(38) O Pedro foi dormir para o quarto.

«The Pedro ir-3.sg.PPerf to-sleep to the bedroom»

«Pedro went to his bedroom to sleep.»

The PP introduced by a ('to') or bypara ('to') seems to be, in these constructions, intimately related to the verb ir('go'), since it can occupy a position immediately adjacent to this lexical item, i.e., it can be inserted between ir ('go') and the

6 For methodological reasons, we are ignoring here some pragmatic readings of ir ('go') + Infinitive illustrated in (i) and (ii):

(i) O João teve azar, foi logo gostar da Maria.

«the João had bad luck, ir-3.sg.PPerf just to-like of-the Maria»

«João was unfortunate. He fell in love just with Maria.»

(ii) Que pena! O meu gato foi logo partir a pata direita.

«What pity! The my cat ir-3.sg.PPerf just to-break the leg right»

«What a pity! My cat just broke his right leg.»

Note that, in order for these sentences to be acceptable, they must include a discursive marker such as logo ('just') and they must be performed with a special intonation. Their meaning is quite different from the one we are dealing with in this paper, since their main function is to establish a strong contrast in the discourse (in the majority of the cases, they express unexpectedness). Because of their specificities, these sentences must be treated separately, requiring a pragmatic discourse-based account. Since their meaning is very disparate from the one we are discussing here, they will not pose special problems for our proposal.

${ }^{7}$ The projection of a Prepositional Phrase introduced by a ('to') or bypara ('to') in the ir ('go') + Infinitive in PPerf construction is actually quite common in EP and can easily be attested in our corpus, as shown in the following examples:

(i) As jovens foram receber tratamento ao Hospital de Santo António (...). (par=ext20401-soc-97b-1)

«The girls ir-3.pl.PPerf to-receive treatment to-the Hospital de Santo António (...)»

«The girls went to the Hospital de Santo António to be treated.»

(ii) Segundo a GNR de Castelo Branco, Luís Miguel, depois de sair da escola, foi brincar para o edifício de uma antiga fábrica de lanifícios em Cebolais de Cima. (par=ext164040-soc-98b-1)

«According the GNR of Castelo Branco, Luís Miguel, after of to-leave of-the school, ir-3.sg.PPerf to-play to the building of an old woolen mill in Cebolais de Cima»

«According to the GNR of Castelo Branco, Luís Miguel, after leaving school, went to the building of an old woolen mill to play in Cebolais de Cima.» 
Infinitive, as shown in (39)-(40):

(39) A Cristina foi à Foz almoçar.

«The Cristina ir-3.sg.PPerf to-the Foz to-have-lunch»

«Cristina went to Foz to have lunch.»

(40) O Pedro foi para o quarto dormir. ${ }^{8}$

«The Pedro ir-3.sg.PPerf to the bedroom to-sleep»

«Pedro went to his bedroom to sleep.»

It is important to point out that this kind of PPs is not normally selected by the verbs that occur in the infinitive form. In fact, if we remove the verb ir ('go') from the whole construction, preserving, nevertheless, the eventualities conveyed by the infinitive predicates with which it combines, we will notice that the PPs introduced by a ('to') or bypara ('to') give rise, in the great majority of the cases, to ungrammatical results, as illustrated in (41) and (42):

(41) A Cristina almoçou * à foz / na Foz.

«The Cristina had lunch * to-the Foz / in-the Foz»

«Cristina had lunch at Foz.»

(42) O Pedro dormiu * para o quarto / no quarto.

«The Pedro slept * to the bedroom / in-the bedroom»

«Pedro slept in his bedroom.»

Since, as shown in (41)-(42), the PPs headed by a ('to') or para ('to') are normally incompatible with the argumenta structure of the infinitive verbs in the constructions we are dealing with, we shall conclude that their presence must be due to some semantic property of the verb ir ('go').

On the other hand, it is interesting to notice that some predications that, in principle, are incompatible with ir ('go') + Infinitive in the PPerf become perfectly acceptable when a PP headed by a ('to') or para ('to') is added to the sentence, as illustrated in (43)-(46). Although much research on this topic must be carried out, I propose the hypothesis that the presence of such PPs somehow "agentivises" the structure, making it compatible with the above-mentioned requirements of ir('go') + Infinitive in the PPerf. ${ }^{9}$ This confirms the relevance and the central role played in these constructions by the Goal argument, acting in the close dependency of the verb ir ('go').

(43) * O Joãofoimorrer.

«The João ir-3.sg.PPerf to-die»

«João went to die.»

(44) O João foi morrer a Paris.

«The Joãoir-3.sg.PPerf to-die to Paris»

«João went to Paris to die.»

(45) * A Rita foichorar.

«The Rita ir-3.sg.PPerf to-cry»

«Rita went to cry.»

\footnotetext{
${ }^{8}$ Note that, for European Portuguese speakers, the position occupied in the sentence by the PP seems to affect its ultimate interpretation. Indeed, when the PP occurs in adjacency to the verb ir ('go'), as illustrated in (39) and (40), a final reading becomes salient. Therefore, these sentences can be paraphrased, respectively, as "Cristina went to Foz in order to have lunch" or "Pedro went to his bedroom in order to sleep". On the contrary, when the PP follows the infinitive cluster, the final reading is virtually lost and the sentence describes a regular past situation in which the PP assumes its habitual thematic role of Goal.

9 Note that the behaviour of the agentive adverbials seems to support this assumption: while "\# $O$ Joãofoimorrervoluntariamente" ( «João went to die voluntarily») is considered odd by Portuguese speakers, "O Joãofoimorrer a Paris voluntariamente" («João went to die in Paris voluntarily») is felt as unquestionably better.
} 
(46) A Rita foi chorar para o quarto.

«The Rita ir-3.sg.PPerf to-cry to the bedroom»

«Rita went to her bedroom to cry.»

In summary, we can say that the combinatorial constraints exhibited by the ir ('go') + Infinitive in the PPerf construction seem to derive, in a great extent, from the fact that the verb ir ('go'), regarding its semantic properties, behaves just like a full lexical item. In particular, (i) ir ('go') retains its dynamic character, ruling out the presence of stative predications; (ii) its tendency to combine with agentive or animate subjects makes it incompatible with non-agentive situations and (iii) it licenses, in the structure, the projection of a PP headed by a ('to') or bypara ('to'), carrying the thematic role of Goal.

From the discussion offered above, we can now summarise some of the most relevant semantic properties that characterise the ir ('go') + Infinitive in the PPerf construction:

- The ir ('go') + Infinitive in the PPerf construction does not carry out any special information about temporal relations between situations, that is, here ir ('go') + Infinitive does not express any temporal value of posteriority.

The range of eventualities that can occur in the context of ir('go') + Infinitive in the PPerfis subject to significant constraints regarding their selection that ultimately seem to be strongly conditioned by the lexical properties of the verb ir ('go').

- The final interpretation of these constructions will, thus, be the result of a dynamic interaction between the main properties and meanings of the verb ir ('go'), taken as a full lexical item, and those of the predications in the Infinitive combining with it.

\section{IR ('GO') + INFINITIVEWITHTHEPRESENTE DO INDICATIVO (PRES)}

When it is combined with the Presente do Indicativo (simple present), the construction ir ('go') + Infinitive raises some significant issues that must be taken into account. Considering some examples in which it occurs, we not only observe that the linguistic behaviour differs considerably from the one exhibited by its counterpart in the PPerf, but we also perceive interpretative divergences between sentences apparently expressing the same linguistic structure.

Based on the observation and discussion of the relevant data, I will propose, in this section, the need to postulate two perfectly distinct constructions: a first one in which aspectual meaning is prominent and ir('go') + Infinitive in the Present exhibits a quantificational (frequentative or habitual) reading (cf. (47)), and a second one in which temporal information is conveyed and the situations in the Infinitive are located in an interval following the utterance time (cf. (48)).

(47) A Maria vai comprar pão todos os dias.

«The Maria ir-3.sg.Pres to-buy bread every the days» «Maria buys bread every day.»

(48) A Maria vai comprar uma casa nova.

«The Maria ir-3.sg.Pres to-buy a house new»

«Maria will buy a new house.»

It is therefore crucial to investigate what semantic properties distinguish these two readings and to explore the better way to describe adequately the differences displayed by their linguistic behaviour.

\subsection{The Quantificational Reading}

Although it is not the default case for this kind of structures, being, indeed, relatively infrequent, the construction ir ('go') + Infinitive in the Pres can get a habitual or frequentative interpretation. This reading presents a pattern of repeated situations that, in general, begins before and goes beyond the utterance time. In these cases, thus, the explicit reference to a future interval is not part of the core meaning of the construction. In fact, it conveys a habitual reading in many respects very close to the one that is normally expressed by the Presente do Indicativo (simple present) when it is combined with events, as illustrated in "O Pedro brinca com osfilhos" («Pedro (usually / habitually) plays with hischildren»). ${ }^{10}$

In the following examples, taken from our corpus, we notice a clearly habitual or frequentative reading, where ir ('go') + Infinitive in the Present expresses some kind of repetition or quantification over situations in an interval that obligatorily

${ }^{10}$ For a detailed discussion about habituality and habitual constructions, see, among many others, Lenci, 1995; Verkuyl, 1995; Lenci\&Bertinetto, 2000; Bertinetto\&Lenci, 2012.Specifically for EuropeanPortuguese, consider Cunha, 2006; Oliveira \& Cunha, 2011 and Cunha, 2012. 
includes the utterance time, being a pure posteriority relation absent from these sentences. ${ }^{11}$

(49) Muito embora não seja permitido cortar o cabelo, os cabeleireiros são visitados com alguma frequência por mulheres islâmicas que vão arranjar o cabelo, as unhas, fazer depilação ou até mesmo maquilhar-se. (par=ext268591-soc-98a-2)

«Very although not be-3.sg.Pres-Sub allowed to-cut the hair, the stylists are visited with some frequency by women Islamic that ir-3.pl.Pres to-arrange the hair, the nails, to-do depilation or even to-make-up»

«Although it is not allowed to cut the hair, stylists are quite often visited by Islamic women who go (there) to assemble their hair, their nails, to do waxing or even to do their make-up.»

(50) Íamos sair, ele todos os dias vai fazer compras, com o "chauffeur". (par=ext1103815-clt-91b-2)

«Ir-1.pl.Imp to-leave, he every the days ir-3.sg.Pres to-do shopping, with the "chauffeur"»

«We were going to leave; he goes (there) every day to do some shopping with his "chauffeur".»

Since it is not the default one, the frequentative or habitual interpretation typically only arises in these constructions when it is triggered by some element quantifying over situations or by some linguistic expression that, in a way or another, conveys information about habituality (cf. (51)-(52)); otherwise, the most salient reading will be the one in which the eventuality is located at a future interval.

(51) A Maria vai visitar a avó habitualmente.

«The Maria ir-3.sg.Pres to-visit the grandmother habitually»

«Maria visits her grandmother habitually.»

(52) O bando de leões vai caçar gnus todas as tardes.

«The group of lions ir-3.sg.Pres to-hunt gnus every the afternoons»

«The group of lions hunts gnus every afternoon.»

However, the occurrence of a quantificational or habitual interpretation in these contexts is subject to strong restrictions. In particular, the licensing of such reading of ir ('go') + Infinitive in the Present seems to share the same constraints we have discussed for its equivalent with the PPerf.

Firstly, the quantificational reading of ir ('go') + Infinitive in the Present is not compatible with stative predications, even though they can be repeated in other contexts (cf. (53)-(54)):

(53) \# A Maria vai ser simpática com as amigas habitualmente.

«The Maria ir-3.sg.Pres to-be kind with the friends habitually»

"Maria is kind to her friends habitually.»

(54) \# O João vai estar doente todos os meses. ${ }^{12}$

«The Joãoir-3.sg.Pres to-be sick every the months»

«João is sick every month.»

On the other hand, non-agentive situations are also ruled out in a frequentative or habitual interpretation of ir ('go') + Infinitive in the Present, as the following examples demonstrate:

(55) \# O motor do meu carro vai trabalhar diariamente.

\footnotetext{
${ }^{11}$ Although I am plainly aware of the fact that there exist considerable semantic differences between habitual and frequentative constructions (cf. Cunha, 2006; 2012), such divergences do not seem to have a significant and direct impact on the linguistic problems that concern us in this paper, i.e., both frequentative and habitual readings behave similarly in the context of ir ('go') + Infinitive in the Present. So, for our purposes, I will ignore such dissimilarities and I will treat here uniformly frequency and habituality.

${ }^{12}$ Note that a futurity reading, in which a habitual state or a frequentative pattern of situations is located in an interval following the utterance time, is perfectly possible for sentences like the ones presented in (53)-(54), but this is not the interpretation that is under discussion now and so I will ignore it for the moment.
} 
«The engine of-the my car ir-3.sg.Pres to-work daily»

«My car's engine works every day.»

(56) \# O relógio da sala vai cair ao chão todas as semanas. ${ }^{13}$

«The clock of-the room ir-3.sg.Pres to-fall at-the ground every the weeks»

«The clock in the room falls to the ground every week.»

Notice, furthermore, that the constraints observed in (53)-(56) cannot simply be justified by the habitual character of the situations involved, since, as the following examples - in which ir ('go') + Infinitive in the Pres is substituted by the simple Present tense form - reveal, such eventualities can occur unproblematically in habitual structures that take place in an interval including the utterance time.

(57) A Maria é simpática com as amigas habitualmente.

«The Maria be-3.sg.Pres kind with the friends habitually»

«Maria is kind to her friends habitually.»

(58) O João está doente todos os meses.

«The João be-3.sg.Pres sick every the months»

«João is sick every month.»

(59) $O$ motor do meu carro trabalha diariamente.

«The engine of-the my car work-3.sg.Pres daily»

«My car's engine works every day.»

(60) O relógio da sala cai ao chão todas as semanas.

«The clock of-the room fall-3.sg.Pres at-the floor every the weeks»

«The clock in the room falls to the floor every week.»

Another characteristic that is shared by the habitual or quantificational reading of ir ('go') + Infinitive in the Present and the ir ('go') + Infinitive in the PPerf constructions has to do with the fact that, in any case, a PP headed by a ('to') or by para ('to') can always be fairly licensed. As I have already pointed out, these PPs seem to depend on the lexical properties of the verb ir('go'). The following examples illustrate this possibility:

(61) A Maria vai visitar a avó à quinta habitualmente.

«The Maria ir-3.sg.Pres to-visit the grandmother to-the farm habitually»

«Maria visits her grandmother at her farm habitually.»

(62) O bando de leões vai caçar gnus para a savana todas as tardes.

«The group of lions ir-3.sg.Pres to-hunt gnus to the savanna every the afternoons»

«The group of lions hunts gnus at the savanna every afternoon.»

In these structures, once again, the PP can be inserted immediately to the right of ir ('go') (cf. (63)-(64)), strengthening the idea that these phrases take part in the argumental grid of the above-mentioned verb. Furthermore, it becomes clear that such PPs depend on the lexical selection of ir ('go'), since they are ruled out as soon as the verb is removed from the structure, as attested in (65)-(66).

(63) A Maria vai à quinta visitar a avó habitualmente.

«The Maria ir-3.sg.Pres to-the farm to-visit the grandmother habitually»

«Maria visits her grandmother at her farm habitually.»

\footnotetext{
${ }^{13}$ Once again, bear in mind that an interpretation in which the whole habitual structure is located at a future interval is perfectly possible; however, what concerns us here is a frequentative or habitual reading that takes place in a period obligatorily including the utterance time. Such an interpretation, as we have seen, is possible for examples like (49)-(52), but not for those in (53)-(56).
} 
(64) O bando de leões vai para a savana caçar gnus todas as tardes.

«The group of lions ir-3.sg.Pres to the savanna to-hunt gnus every the afternoons»

«The group of lions hunts gnus at the savanna every afternoon.»

(65) * A Maria visita a avó à quinta habitualmente.

«the Maria to-visit-3.sg.Pres the grandmother to-the farm habitually»

«Maria visits her grandmother at her farm habitually.»

(66) * O bando de leões caça gnus para a savana todas as tardes.

«The group of lions to-hunt-3.sg.Pres gnus to the savanna every the afternoons»

«The group of lions hunts gnus at the savanna every afternoon.»

The linguistic behaviour of the sentences we have just discussed suggests, therefore, that, in the frequentative or habitual reading of ir ('go') + Infinitive in the Present, the PPs headed by a ('to') or by para ('to) are strictly dependent on the lexical features of the verb ir ('go'). This leads us to believe that, in the context under consideration, such verb retains its main lexical properties, in a very similar way it does in the equivalent structures with the PPerf.

Given the above discussion, if we assume that, in these configurations, ir ('go') shows up some properties of a full lexical item, we get a good explanation for the habitual reading displayed in such sentences. Indeed, if we take into account that (i) ir ('go'), in the relevant contexts, is restricted to occur with eventive(agentive) predications and that (ii) in general, events combining with the Present tense preferentially give rise to quantificational (frequentative or habitual) interpretations (cf. Cunha, 2006; 2012), then it will not be surprising that ir ('go') + Infinitive in the Present in its quantificational reading combines some lexical features of ir ('go), viz. its eventive character, with properties of the Present tense, viz. the habituality reading with events.

To conclude, let us summarise the most relevant properties exhibited by the ir ('go') + Infinitive in the Present construction in its frequentative or habitual reading:

- In this particular reading, ir ('go') + Infinitive in the Present tense does not convey any special temporal information, i.e., it does not locate the described situations in a future interval; instead, it carries aspectual information about the repetition or the quantification of the eventualities involved.

- Once again, ir ('go') seems to preserve some of the most relevant properties that characterise such verb as a full lexical item. In particular, it does not combine with stative predications nor with non-agentive eventualities and it always licenses PPs headed by a ('to') or para ('to') in the construction.

- The final interpretation of this kind of structures seems to be the natural outcome of the interaction between some of the most relevant properties of the lexical verb ir ('go') and the semantic effects of the Presente do Indicativo (simple Present tense). In fact, the habitual reading that arises in these constructions can be thought as the ordinary consequence of the co-occurrence of an eventive predication, associated to the verb ir('go'), with the expected quantificational effects of the Present tense.

\subsection{The Future Temporal Reading}

In the great majority of its occurrences, however, the structure ir ('go') + Infinitive in the Present conveys temporal information of posteriority. In particular, it locates the situations in its scope in an interval that is subsequent to the utterance time. The use of ir ('go') + Infinitive as a future tense has long been recognised in the literature about tense in European Portuguese (see, among many others, Oliveira, 1986; Peres, 1993; Oliveira \& Lopes, 1995; and, for Brazilian Portuguese, Silva, 1997). In these contexts, ir ('go') behaves just like a temporal semi-auxiliary, as defined in Gonçalves\& Costa (2002). Such semi-auxiliary operates on the situations expressed by the infinitives, locating them in an interval that must follow the utterance time. Consider the sentences in (67) and (68), taken from our corpus, that illustrate this kind of interpretation:

(67) Para gerir a nova rede, bem como as de outros clientes, o operador de telecomunicações norte-americano vai criar um novo centro de suporte a clientes em Dublin, Ohio. (par=ext1544730-com-98b-4)

«To manage the new network, well as those of other customers, the operator of telecommunications north-americanir-3.sg.Pres to-create a new center of support to customers in Dublin, Ohio»

«In order to manage the new network, as well as those of new customers, the North-American telecommunications operator will create a new customer support center in Dublin, Ohio.»

(68) O Banco Português de Investimento vai comprar o Banco Fonsecas\& Burnay pelo valor mínimo, a base de licitação. (par=ext788828-eco-91b-4) 
«The Banco Português de Investimentoir-3.sg.Pres to-buy the Banco Fonsecas\&Burnay by-the value minimum, the base of licitation»

«The Banco Português de Investimento will buy the Banco Fonsecas\&Burnay spending the minimum price, its base bid.»

In the context of ir('go') + Infinitive in the Present tense, the above-mentioned temporal future reading seems to be quite common and it surely is the default interpretation for these sentences, unless linguistic or contextual information alters the picture. As we will see shortly, the properties and the semantic behaviour of this kind of structure differ considerably from the ones that characterise the ir ('go') + Infinitive with PPerf and with Pres in its frequentative or habitual reading.

Firstly, and contrary to the cases discussed so far, we do not find significant restrictions regarding the aspectual class of the situations that can combine with ir ('go') + Infinitive. In particular, the future reading of ir ('go') + Infinitive in the Pres is perfectly compatible with stative predications (cf. (69)-(70)) and with non-agentive constructions (cf. (71)-(72)):

(69) (Na festa de amanhã,) a Maria vai ser simpática com as amigas.

«(In-the party of tomorrow,) the Maria ir-3.sg.Pres to-be kind with the friends»

«(In tomorrow's party,) Maria will be kind to her friends.»

(70) (Se continuar a apanhar frio,) amanhã o João vai estar doente.

«(If continue-3.sg.Fut.Subj to-get cold,) tomorrow the Joãoir-3.sg.Pres to-be sick»

«(If he continues to get cold,) tomorrow João will be sick.»

(71) (Com o arranjo que lhe fiz,) o motor do meu carro vai trabalhar.

«(With the arrangement that it do-1.sg.PPerf,) the engine of-the my car ir-3.sg.Pres to-work»

«(Thanks to the arrangement I did to it,) my car's engine will work.»

(72) (Tem cuidado!) O relógio da sala vai cair ao chão.

«(Have caution!) The clock of-the room ir-3.sg.Pres to-fall to-the floor»

«(Be careful!) The clock in this room will fall to the ground.»

Notice that, as the following examples show, in its posteriority interpretation, ir ('go') + Infinitive with Pres can freely occur with any kind of stative, irrespective of its subclass. This fact strengthens the idea that, in cases like these, aspectual constraints have no significant repercussion on the licensing of the structure at issue.

(73) (Quando crescer,) a Joana vai ser médica. (individual-level non-phase state)

«(When grow-up-3.sg.Fut.Subj,) the Joana ir-3.sg.Pres to-be doctor»

«(When she grows up,) Joana will be a doctor.»

(74) (Quando o ladrão entrar no jardim,) o meu cão vai ser agressivo. (individual-levelphasestate)

«(When the thief entre-3.sg.Fut.Subj in-the garden,) the my dog ir-3.sg.Pres to-be aggressive»

«(When the thief enters the garden,) my dog will be aggressive.»

(75) (Amanhã) o João vai estar em Paris. (stage-level non-phase state)

«(Tomorrow) the Joãoir-3.sg.Pres to-be in Paris»

«(Tomorrow) João will be in Paris.»

(76) (Amanhã) o Filipe vai ter dificuldades no exame. (stage-levelphasestate)

«(Tomorrow) the Filipe ir-3.sg.Pres to-have difficulties in-the examination»

«(Tomorrow) Filipe will experiment difficulties in his examination.»

Given that, in this kind ofcontexts, ir ('go') behaves as a true temporal semi-auxiliary (see the discussion and the arguments put forward in Gonçalves\& Costa, 2002), it is expectable that this verb loses most of its relevant lexical propertiesconsidered above. Indeed, this fact would explain, on the one hand, the lack of aspectual constraints that we have just observed and, on the other, the inability, under specific circumstances, to project PPs headed by a ('to') or bypara ('to'). So, while, as we have pointed out, it is always possible to introduce this type of PPs in structures where ir 
('go') + Infinitive occurs in the PPerf or displays a quantificational/habitual reading in the Present, the same does not happen when the future temporal reading is chosen. In particular, these prepositional phrases seem to be systematically excluded from ir ('go') + Infinitive in the Present with future reading structures whenever a stative or a non-agentive predication is selected, as the following examples illustrate: ${ }^{14}$

(77) A Susana vai ser professor * a / * para / em Lisboa.

«The Susana ir-3.sg.Pres to-be teacher * to / * to / in Lisbon»

«Susana will be teaching in Lisbon.»

(78) Amanhã o João vai estar contente * à / * para a / na sua festa de anos.

«Tomorrow the Joãoir-3.sg.Pres to-be happy * to-the / to the / in his party of birthday»

«Tomorrow João will be happy at his birthday party.»

(79) Amanhã vai chover * ao / * para o / no norte do país.

«Tomorrow ir-3.sg.Pres to-rain * to-the / * to the / in the north of-the country»

«Tomorrow it will rain in the north.»

(80) O fogo vai queimar as árvores * à / * para a / na floresta.

«The fire ir-3.sg.Pres to-burn the trees * to-the / * to the / in the forest»

«Fire will burn the trees in the forest.»

In short, the data concerning the combinatorial possibilities with aspectual classes and the pattern of licensing of PPs headed by a ('to') or bypara ('to') strongly suggest that ir ('go') (+ Infinitive), when combined with the simple Present tense, in its temporal future reading, loses the majority of its basic lexical properties, behaving as a purely functional element, viz. as a temporal operator of posteriority.

Let us summarise now the most relevant properties that characterise the configuration we have been discussing in the present subsection:

- When the future temporal reading is selected, ir ('go') + Infinitive in the Pres acts as a true tense form, locating the described situations in an interval that necessarily follows the utterance time.

- In such structures, ir ('go') seems to lose most of its lexical basic properties. This explains, on the one hand, the complete absence of constraints regarding the aspectual class of the predications that can co-occur in the construction, and, on the other, the impossibility, under well-defined circumstances, of inserting prepositional phrases headed by a ('to') or by para ('to').

- $\quad$ The verb ir ('go') thus behaves here as a true temporal semi-auxiliary, as defined in Gonçalves\& Costa (2002), being its main semantic contribution that of locating a situation in a future interval with respect to the selected Temporal Perspective Point (cf. Kamp \&Reyle, 1993).

\subsection{Cases DisplayingAmbiguity}

If the proposal I have been presenting in this paper is correct, i.e., if the ir ('go') + Infinitive in the Pres

\footnotetext{
${ }^{14}$ It is important to notice, however, that PPs headed by a ('to') or by para ('to') can nevertheless be introduced in structures where non-stative [+agentive] predications are involved, even though the future temporal reading is unequivocally selected, as illustrated in (i) and (ii).
}

(i) Amanhã, a Maria vai visitar a avó à quinta. «Tomorrow, the Maria ir-3.sg.Pres to-visit the grandmother to-the farm» «Tomorrow, Maria will visit her grandmother at her farm.»

Amanhã, o bando de leões vai caçar gnus para a savana «Tomorrow, the group of lions ir-3.sg.Pres to-hunt gnus to the savanna» «Tomorrow, the group of lions will hunt gnus at the savanna.»

Discussing similar examples, Gonçalves\& Costa (2002: p. 73, footnote 49) argue that such configurations result from the fact that the semi-auxiliaries ir ('go') and vir ('come') preserve residual characteristics of the verbs of motion from which they are derived. Although it is not my goal here to explore this problem further, I think it would be interesting to investigate the circumstances in which the "residual" properties of the above-mentioned semi-auxiliaries remain "active", since, as we have seen, there seems to be some variability in this regard. 
sequencesareinvolved in two different linguistic constructions - a first one in which the verb ir ('go') preserves its main lexical properties and a second one in which it performs the role of a pure temporal operator -,then it would be possible to find examples in which the above-mentioned structures show up some kind of ambiguity in their interpretative possibilities.

Indeed, this prediction seems to be born out, provided that some important conditions are met. Thus, sentences (i) in which ir ('go') + Infinitive in the Present combines with non-stative [+agentive] predications and (ii) in which a PP headed by a ('to') or bypara ('to') is overtly projected consistently show interpretative ambiguity. Consider the following examples:

(81) A Maria vai fazer compras ao supermercado.

«The Maria ir-3.sg.Pres to-do shoppings at-the supermarket»

«Maria does / will do her shopping at the supermarket.»

(82) O João vai estudar para a biblioteca.

«The Joãoir-3.sg.Pres to-study to the library»

«João studies / will study in the library.»

For native speakers of European Portuguese, two different interpretations are easily available when they are faced with examples like these.

On the one hand, sentences (81) and (82) can get a quantificational (frequentative or habitual) reading, in which the situations are repeated in a time interval that typically includes the utterance time, describing a recurrent pattern of occurrences. They are paraphrasable as "Habitually, Maria does her shopping at the supermarket" or "Generally, João studies in the library". In this case, ir('go') behaves just like a full lexical item, being the quantificational reading the result of the interaction between the aspectual properties of the Simple Present and the eventive character of the eventualities involved.

On the other hand, it is possible to assign to these sentences a simple future reading, in which the situations are located in a time interval obligatorily following the utterance time. The relevant paraphrases, in this case, are "Maria will do her shopping at the supermarket" or "João will study in the library". Here, ir ('go') acts as a pure temporal semi-auxiliary, as described in subsection 3.2.

It should be stressed, nonetheless, that all the above-mentioned conditions must be met in order to obtain this kind of ambiguity. In fact, sentences where ir ('go') + Infinitive in the Present tense combines with stative or non-agentive predications can only get a temporal future reading, being unable to display a frequentative or habitual one, as discussed in section 3.2 (cf. examples (69)-(72)).

Summing up, the existence of cases of ambiguity like the ones observed in examples (81) and (82) contribute to strengthen the hypothesis put forward in this paper according to which there are two differentir('go') + Infinitive constructions: one in which ir ('go') retains its basic lexical properties and another in which it behaves as a pure temporal operator.

\section{BRIEFREMARKSONSOME OTHER PORTUGUESETENSES}

Although it is not the aim of this paper to deeply discuss the construction ir ('go') + Infinitive with tenses other than the PretéritoPerfeito (terminative simple past) and the Presente do Indicativo (simple present), I would like to briefly sketch some observations about the combinatorial possibilities of this structure with other European Portuguese tenses.

It seems that, in the current stage of the development of European Portuguese, the pure temporal reading of ir + Infinitive is confined to a limited number of tenses, namely the Presente do Indicativo (simple present) and the Imperfeito (imperfect). ${ }^{15}$ In contrast, all Portuguese tenses - including compound ones - freely accept the ir ('go') + Infinitive construction when ir ('go') preserves its basic lexical properties.

Such assertion can be confirmed by the contrasts in acceptability displayed by the following examples:

(83) A Ana vai estar na biblioteca (amanhã).

«The Ana ir-3.sg.Pres to-be in-the library (tomorrow)»

«Ana will be in the library (tomorrow).»

(84) A Ana ia estar na biblioteca (no dia seguinte).

«The Ana ir-3.sg.Imp to-be in-the library (in-the day next)»

15 Further investigation is needed in order to evaluate if the pure temporal reading is available for other Portuguese tenses like the so-called Conditional and the subjunctive forms. I leave this question open for a future research. 
«Ana would be in the library (the next day).»

(85) * A Ana foi estar na biblioteca.

«The Ana ir-3.sg.PPerf to-be in-the library»

"Ana went to be in the library.»

(86) * A Ana tinha ido estar na biblioteca (quando conheceu o Rui).

«The Ana ir-3.sg.MQPerf-Comp to-be in-the library (when met the Rui)»

«Ana had gone to be in the library (when she met Rui).»

(87) * A Ana tem ido estar na biblioteca.

«The Ana ir-3.sg.PPerf-Comp to-be in-the library»

«Ana has gone to be in the library.»

As we have pointed out above, states like "estarnabiblioteca" («to be in the library») can only combine with ir ('go') + Infinitive when ir ('go') is taken as a temporal semi-auxiliary leading to a posteriority reading. This possibility is only available when the Presente do Indicativo (simple present) or the Imperfeito (imperfect) are involved (cf. (83)-(84)); otherwise, i.e., when ir ('go') + Infinitive combines with the PretéritoPerfeito (terminative past tense; cf. (85)), the Mais-quePerfeito (pluperfect; (cf. (86)) or the PretéritoPerfeitoComposto (a compound past tense; cf. (87)), we get semantic anomaly and the sentences are ruled out.

The picture changes considerably if we take into account agentive events. In this case, every Portuguese tense can cooccur with the structureir ('go') + Infinitive. Moreover, besides its posteriority reading, configurations with the Presente do Indicativo (simple present) or the Imperfeito (imperfect) can easily display a quantificational interpretation, as illustrated in (88) and (89). Note that, although they can take part in these contexts, the other Portuguese tenses - namely the PretéritoPerfeito, the Mais-que-Perfeito and the PretéritoPerfeitoComposto - never bring about a posteriority reading and ir ('go') typically retains its basic lexical properties (cf. (90)-(92)).

(88) O Luís vai comprar chocolates (todos os dias).

«The Luísir-3.sg.Pres to-buy chocolates (every the days)»

«Luís buys chocolates (every day).»

(89) O Luís ia comprar chocolates (todos os dias).

«The Luísir-3.sg.Imp to-buy chocolates (every the days)»

«Luís used to buy chocolates (every day).»

(90) O Luís foi comprar chocolates.

«The Luísir-3.sg.PPerf to-buy chocolates»

«Luís went to buy chocolates.»

(91) O Luís tinha ido comprar chocolates (quando conheceu a Maria).

«The Luísir-3.sg.MQPerf-Comp to-buy chocolates (when met the Maria)»

«Luís had gone to buy chocolates (when he met Maria).»

(92) O Luís tem ido comprar chocolates.

«The Luísir-3.sg.PPerf-Comp to-buy chocolates»

«Luís has been going to buy chocolates.»

In sum, if the proposals we have been presenting in this paper are on the right track, it is possible to draw some conclusions from the examples offeredabove. In particular: (i) there are actually two different constructions involving ir ('go') + Infinitive, one of which, viz. the one in which ir ('go') preserves its basic lexical properties, is sensitive to aspectual and animacy constraints; (ii) the posteriority temporal reading associated with ir ('go') + Infinitive is only available for some Portuguese tenses, namely the Presente do Indicativo and the Imperfeito (cf. (83)-(84) vs. (85)-(87)); and (iii) although the ir ('go') + Infinitive construction in whichir ('go') preserves most of its basic lexical properties cannot combine with every kind of eventuality, it may, nevertheless, freely co-occur with every Portuguese tense.

In order to validate and refine our proposals, much more work must be done. In particular, the interaction between their ('go') + Infinitive construction and other European Portuguese tenses has to be tested and scrutinised; moreover, it would be fruitful to compare the synchronic facts described here with the diachronic development of the structure at issue. I will, however, leave these complex problems to a future research. 


\section{CONCLUSIONS}

In the course of this paper I have discussed some important divergences that can be found when we analyse the semantic behaviour of the ir ('go') + Infinitive construction in the context of two different European Portuguese tenses, namely the Presente do Indicativo (simple present) and the PretéritoPerfeito (terminative past tense). I have argued for the idea that there exist actually two distinct structures involving ir ('go') + Infinitive.

In one of these constructions, ir ('go') preserves most of its basic lexical properties. In particular, it conserves its dynamic and agentive character, being only compatible with infinitive situations that are eventive and select an animate subject. Moreover, PPs introduced by a ('to') or para ('to'), mandatory in the pure lexical use of ir ('go'), are always licensed in the contexts under analysis.

In its temporal reading, however, ir ('go') (+ Infinitive) seems to lose its lexical properties. In fact, it acts as a simple temporal operator, or as a future tense, locating the eventualities combining with it in a future time interval. Every kind of situation is compatible with this use of ir ('go') + Infinitive, including all subclasses of states and non-agentive events. Moreover, the projection of the above-mentioned PPs is sometimes impossible in these contexts.

In sum, the syntactic and semantic differences just mentioned plainly justify the postulation of the existence, in European Portuguese, of two constructions involving ir ('go') + Infinitive. Although we have not deeply exploited this topic, it became clear that the analysis of the behaviour of such sequence regarding other Portuguese tenses confirms our findings.

\section{REFERENCES}

[1] Bertinetto, P.M.,\&Lenci, A. 2012.Pluractionality, habituality and gnomic imperfectivity.In R. Binnick (ed.), Oxford Handbook of Tense and Aspect. Oxford, Oxford University Press: pp. 852-880.

[2] Binnick, R. 1991.Time and the Verb: a Guide to Tense and Aspect. Oxford, OxfordUniversityPress.

[3] Cunha, L. F. 1999. Breve análise semântica de alguns operadores aspectuais do Português. InActas do XIV Encontro Nacional da Associação Portuguesa de Linguística. Braga, APL: pp. 447-462.

[4] Cunha, L. F. 2004.Semântica das Predicações Estativas: para uma Caracterização Aspectual dos Estados. PHD Dissertation, Oporto, Faculdade de Letras da Universidade do Porto. Published 2007, München, Lincom Europa.

[5] Cunha, L. F. 2006. Frequência vs. habitualidade: distinções e convergências. InActasdel XXXV Simpósio Internacional de laSociedadEspañola de Lingüística. León, SEL: pp. 333-357. Available on-line at http://www3.unileon.es/dp/dfh/SEL/actas/Cunha.pdf

[6] Cunha, L. F. 2012. Frequentative and habitual structures: similarities and differences. In C. Schnedecker\& C. Armbrecht (eds.), La Quantification etsesDomains - Actes du Colloque de Strasbourg. Paris, Honoré Champion Éditeur: pp. 339-352.

[7] Declerck, R. 2006. The Grammar of the English Tense System.Berlin, Mouton de Gruyter.

[8] Dowty, D. 1979. Word Meaning and Montague Grammar.Dordrecht,ReidelPublishingCompany.

[9] Gonçalves, A. 2002. Verbos auxiliares e verbos de reestruturação do Português Europeu. In I. M. Duarte, J. Barbosa, S. Matos \& T. Hüsgen (eds.), Actas do Encontro Comemorativo dos 25 Anos do Centro de Linguística da Universidade do Porto, Vol. 2. Oporto, Centro de Linguística da Universidade do Porto: pp. 45-57.

[10] Gonçalves, A.\& Costa, T. 2002.(Auxiliar a) Compreender os Verbos Auxiliares do Português - Descrição e Implicações para o Ensino do Português como Língua Materna. Lisbon,Colibri / Associação de Professores de Português.

[11] Kamp, H.\&Reyle, U. 1993.From Discourse to Logic.Introduction to Model-Theoretic Semantics of Natural Language, Formal Logic and Discourse Representation Theory.Dordrecht, Kluwer Academic Publishers.

[12] Lenci, A. 1995.The semantic representation of non-quantificational habituals. In P.M. Bertinetto, V. Bianchi, J. Higginbotham \& M. Squartini (eds.), Temporal Reference, Aspect and Actionality, Vol. 1: Semantic and Syntactic Perspectives. Torino, Rosenberg \&Sellier: pp. 143-158.

[13] Lenci, A.\&Bertinetto, P. M. 2000. Aspects, adverbs, and events: habituality vs. perfectivity. In J. Higginbotham, F. Pianesi\& A. C. Varzi (eds.), Speaking of Events. New York / Oxford, Oxford University Press: pp. 245-287.

[14] Moens, M. 1987.Tense, Aspect and Temporal Reference.PhDDissertation, EdinburghUniversity.

[15] Oliveira, F. 1986. O Futuro em Português: alguns aspectos temporais e/ou modais. InActas do I Encontro Nacional da Associação Portuguesa de Linguística. Lisbon, Associação Portuguesa de Linguística: pp. 353-374.

[16] Oliveira, F., Cunha, L. F.\& Gonçalves, A. 2004.Aspectual verbs in European and Brazilian Portuguese. InJournalofPortugueseLinguistics, 3 (1): pp. 141-173. 
[17] Oliveira, F.\& Lopes, A. C. M. 1995.Tense and aspect in Portuguese. In R. Thieroff (ed.), Tense Systems in European Languages, Vol II.Tübingen, Niemeyer: pp. 95-115.

[18] Oliveira, F.\& Cunha, L. F. 2011. Tipos de genericidade. In A. Costa, I. Falé \& P. Barbosa (orgs.), XXVI Encontro Nacional da Associação Portuguesa de Linguística - Textos Seleccionados. Lisbon, Associação Portuguesa de Linguística: pp. 446-459.

[19] Oliveira, V. M. 2008. A gramaticalização do verbo ir em predicações complexas. InCadernos do Congresso Nacional de Lingüística e Filologia. Vol. XI, n.ํ 12. Rio de Janeiro, Círculo Fluminense de Estudos Filológicos e Lingüísticos: pp. 34-45.

[20] Oliveira, V. M. 2010. Processos de expansão semântica em predicações com o verbo ir. InEstudos Linguísticos, 39 (1): pp. 331-341.

[21] Peres, J. A. 1993. Towards an Integrated View of the Expression of Time in Portuguese.Cadernos de Semântica, n. ${ }^{\circ}$ 14. Lisbon, Faculdade de Letras da Universidade de Lisboa.

[22] Silva, A. 1997.A Expressão da Futuridade na Língua Falada. PhDDissertation, Campinas, São Paulo, Universidade Estadual de Campinas - Instituto de Estudos da Linguagem.

[23] Verkuyl, H. 1995.Indices and habituality. In P.M. Bertinetto, V. Bianchi, J. Higginbotham \& M. Squartini (eds.), Temporal Reference, Aspect and Actionality, Vol. 1: Semantic and Syntactic Perspectives. Torino, Rosenberg \&Sellier: pp. 195-217. 